\title{
PALEONTOLOGICAL OVERVIEW FOR THE WESTERN UNITED STATES
}

Supporting report to the

Draft Vegetation Treatments Using Herbicides on Bureau of

Land Management Lands in 17 Western States Programmatic EIS 

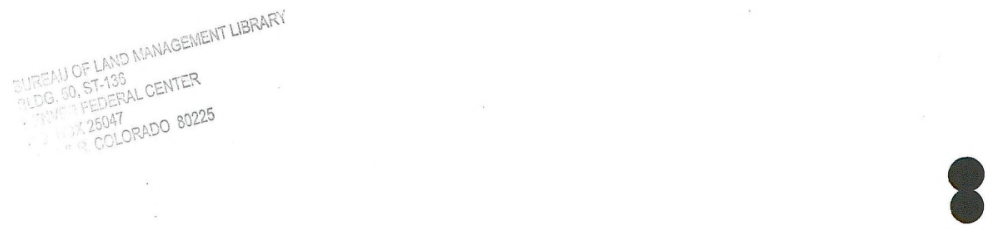


\section{PALEONTOLOGICAL OVERVIEW FOR THE WESTERN UNITED STATES}

The BLM is responsible for managing public lands and their various resources so that they are utilized in a manner that will best meet the present and future needs of this Nation. The western U.S. has a fossil record that includes almost all of the geologic periods from the Cambrian (500+ million years ago) to the more Recent (the last 10,000 years), and nearly every imaginable ancient environment (Table 1). Many fossil deposits are of national and international importance, and many thousands of different kinds of fossils were originally made known to the scientific world from specimens first found in the west.

The BLM manages fossils as a natural heritage resource on public lands under the general guidance of the Federal Land Policy and Management Act and National Environmental Policy Act. Fossils are managed to promote their use in research, education, and recreation, and paleontological localities are an important consideration in developing land use management decisions. More than 200 properties, totaling more than 5 million acres, are managed either wholly or in part for paleontological values or contain paleontological values that may require special management strategies in the future. Significant paleontological resources can also be found on other public lands estimated to total over 20 million acres. Because of the increasing interest and activity related to fossils over the past 3 decades, it is estimated that there are more than 50,000 fossil sites documented on public lands.

A fossil is defined as the remains, trace, or imprint of a plant or animal that has been preserved in a geologic context, and is more than 10,000 years old. This paleontological overview summarizes in general terms what kinds of fossils occur in 17 western states where BLM vegetation treatments would occur. Sources of information are provided at the end of each section for each state.

Fossils are grouped into the following categories for this overview: trace, plant, invertebrate, fish, amphibian, reptile, dinosaur, bird, mammal, and vertebrate. Table 2 shows the occurrence of these fossil types for each state through geologic time. A trace fossil (ichnofossil) is a track, trail, burrow, or tube formed by the activity of an animal. Coprolites, or fossilized dung, are also trace fossils. Fossilized plants occur as physical remains (e.g., petrified wood) or imprints (e.g., leaf impressions). Stromatolites (laminated algal mounds) and Cyanobacteria (blue-green algae) are included in the plant category. Invertebrates are animals without backbones that inhabit marine, freshwater, and terrestrial environments, although this overview does not differentiate the different forms. Animals with backbones, or vertebrates, are subdivided into fish, amphibian, reptile, dinosaur, bird, mammal, and vertebrate. The latter subdivision is used when unspecified or unidentified vertebrate remains are mentioned in the literature. As with invertebrates, differentiation between marine, freshwater, or terrestrial vertebrates is not included. The reptile category includes a variety of animals such as thecodonts (primitive reptiles), crocodiles, marine reptiles (e.g., mosasaurs), flying reptiles (pterosaurs), lizards, snakes, and turtles.

\section{Alaska}

Invertebrates are found throughout the Paleozoic Era record in Alaska. However, vertebrate remains do not appear until the beginning of the Mesozoic Era in Triassic-age rocks, which also contain invertebrates. Invertebrates and trace fossils have been found in Jurassic Period formations. Cretaceous-age units have produced many different types of fossils, including traces, plants, invertebrates, fish, reptiles, dinosaurs, birds, and mammals. With the exception of rare turtle remains, reptiles and amphibians are conspicuously absent. Their absence is thought to be a reflection of climatic conditions in Alaska during the Cretaceous Period, rather than a preservational bias. Plants occur in Paleogene-age rocks, whereas Neogene-age units have produced both plant and invertebrate fossils. Pleistocene-age sediments contain plant, invertebrate, bird, and mammal remains (Ransom 1964; Murray 1967; Weishampel et al. 1990; Santucci 1993; Thurston and Fujita 1994; Connor and O'Haire 2001). 


\section{Arizona}

The fossil record in Arizona extends back into the Precambrian Era, where algal reef forms and jellyfish have been found in Proterozoic-age rocks. Cambrian- and Devonian-age invertebrates, and Devonian-age fish occur. Plant and invertebrate fossils are found in Mississippian- and Pennsylvanian-age units. Permian-age fossils include the physical remains of plants, invertebrates, and fishes, as well as amphibian and reptile tracks. Triassic-age rocks produce many different types of fossils including traces, plants, invertebrates, fishes, amphibians, reptiles, and dinosaurs. Petrified Forest National Park in Arizona showcases and protects many of these unique Triassic-age fossils. Invertebrates, trace fossils, and unspecified vertebrate remains are reported from Jurassic-age rocks. Cretaceous formations contain plant, invertebrate, fish, reptile, and dinosaur remains, along with trace fossils. Neogene-age fossils include traces, plants, invertebrates, reptiles, and mammals. Invertebrate, amphibian, reptile, and mammal remains occur in Pleistocene-age sediments (Lane 1946; Denison 1951; Ransom 1964; Gelbach 1965; Murray 1967; Chronic 1989; Weishampel et al. 1990; Santucci 1993; Daniels 1998; Holman 2000).

\section{California}

Although invertebrates dominate the Paleozoic-age fossil record in California, fish have been found in Devonian- and Permian-age rocks. Triassic-age fossils include invertebrate and reptile remains. Plants and invertebrates occur in Jurassic-age rocks. Cretaceous units have produced plant, invertebrate, reptile, and dinosaur fossils, although the latter are uncommon. Paleogene-age rocks contain plants, invertebrates, reptiles, and mammals. Neogene- and Pleistoceneage sediments contain many different types of fossils-plants, invertebrates, fishes, amphibians, reptiles, birds, and mammals. In addition, Neogene-age trace fossils have also been reported. Rancho La Brea Tar Pits is one of the best Pleistocene-age fossil localities known. Owned by Los Angeles County, the locality is located in the middle of Los Angeles, California, and registered as a National Natural Landmark. Numerous Ice Age fossils have been excavated and include saber-toothed cat, dire wolf, giant sloth, mammoth, mastodon, dwarf pronghorn, short-faced bear, lion, horse, bison, coyote, rodent, fish, amphibian, reptile, bird, insect, and plant remains (Bode 1935; Wilson 1935a, b; Wheeler 1939; Lane 1947a; Ransom 1964; Gelbach 1965; Murray 1967; Weishampel et al. 1990; Santucci 1993; Sharp and Glazner 1993; Alt and Hyndman 1995, 2000; Holman 2000).

\section{Colorado}

The oldest fossils found in Colorado are Cambrian-age invertebrates. Primitive, jawless, armored fish (ostracoderms) occur in Ordovician-age rocks along with trace fossils and invertebrates. Fishes and invertebrates also occur in the Devonian-age rocks. Mississippian-age invertebrates, Pennsylvanian-age plants and invertebrates, and Permian-age invertebrates and reptiles have been reported in this state. Trace fossils, plants, fishes, amphibians, and reptiles occur in Triassic-age formations. Jurassic and Cretaceous-age units have produced many different types of fossils including traces, plants, invertebrates, fishes, reptiles, dinosaurs, and mammals. Paleogene-age fossils include plants, invertebrates, fishes, amphibians, reptiles, birds, and mammals. Florissant Fossil Beds National Monument in Colorado contains thousands of exceptional insect and plant fossils preserved in Oligocene (Paleogene)-age lake deposits. Although Neogene-age rocks are uncommon in Colorado, some mammal and unspecified vertebrate remains have been reported. Pleistocene-age mammal, reptile, invertebrate, and plant remains occur as well (Akersten et al. n.d.; Denison 1951; Ransom 1964; Murray 1967; Lundberg 1975; Kuntz et al. 1989; Weishampel et al. 1990; Santucci 1993; Chronic 1994a; Holman 2000).

\section{Idaho}

Proterozoic-age worm trails and stromatolites are the oldest fossils found in Idaho. Stromatolites are mounded structures composed of alternating layers of blue-green algae and sediment. They are found today in warm, shallow, marine environments and the layers form as mats of blue-green algae trap sedimentary material, grow above the sediment cover, and trap more sediments. Invertebrates occur in the Cambrian-, Ordovician-, Mississippian-,

Vegetation Treatments on BLM Lands in Western U.S. 
Pennsylvanian-, and Permian-age, and fish are found in the Devonian-age units. Triassic-age rocks contain reptiles, fishes, and invertebrates. Plant and invertebrate remains occur in Jurassic-age units. Dinosaurs and reptiles are found in Cretaceous-age rocks of southeastern Idaho along with invertebrates, plants, and trace fossils. Paleogene-age fossils are limited to plant remains, whereas Neogene-age fossils are much more diverse and include mammals, birds, reptiles, amphibians, fishes, invertebrates, and plants. One such Neogene-age locality is Hagerman Fossil Beds National Monument, which is internationally significant for its Pliocene-age fossils. Of note are fossilized "horses" that are more closely related to zebras in Africa than they are to horses. Other animals include the camel, pronghorn, cat, peccary, otter, bear, sloth, hyena-like dog, beaver, shrew, mole, muskrat, giant marmot, turtle, catfish, snake, cormorant, and swan. Pleistocene-age sediments contain mammal, bird, reptile, amphibian, fish, invertebrate, and plant fossils (Akersten et al. n.d.; Shimer and Schrock 1944; Ransom 1964; Murray 1967; Lundberg 1975; Dorr 1985; Alt and Hyndman 1995; Holman 2000).

\section{Montana}

Stromatolites, trace fossils, and invertebrates are found in some Proterozoic-age rocks of Montana. Invertebrates such as trilobites occur in Cambrian-age units. Ordovician-age units contain worm burrows, and invertebrate and fish remains, and Silurian-age rocks, although uncommon, have produced stromatolites and invertebrates. Fishes, invertebrates, and trace fossils occur in Devonian-age units. Mississippian-age invertebrates and trace fossils are found, as are Pennsylvanian-age invertebrates and fish. Permian-age rocks have produced invertebrates, stromatolites, and sometimes fish remains. Invertebrates are the only type of fossil reported from Triassic-age rocks. Jurassic-age rocks contain dinosaur remains along with invertebrates and plants. All fossil types are found in Cretaceous-age rocks, including dinosaur, bird, mammal, reptile, amphibian, fish, invertebrate, plant, and trace. Makoshika State Park near Glendive, Montana, is a complex of badlands where the Hell Creek Formation and its suite of fossils are exposed, including dinosaurs such as Triceratops and Tyrannosaurus. Other exposures of the Hell Creek Formation near Fort Peck Reservoir on the Missouri River are registered as a National Natural Landmark. Paleogene-age units have produced remains of fossilized plants, invertebrates, fishes, amphibians, reptiles, birds, and mammals. Mammal, reptile, and invertebrate fossils occur in Neogene-age rocks, and Pleistocene-age sediments contain mammals, fishes, and invertebrates (Willis 1902; Deis 1939; Shrimer and Shrock 1944; Ransom 1964; Murray 1967; Balster 1971; Rasmussen 1974; Alt and Hyndman 1986; Carroll 1988; Horner 1989; Weishampel et al. 1990; Holman 2000; Hill 2001).

\section{Nebraska}

Pennsylvanian- and Permian-age rocks in Nebraska contain invertebrates. Cretaceous-age rocks have produced invertebrates, reptiles, dinosaur remains, and a dinosaur track. Mammal and reptile remains occur in Paleogene-age units. In addition to trace fossils, Neogene-age deposits contain mammal, bird, reptile, amphibian, fish, invertebrate, and plant remains. Agate Fossil Beds National Monument in northwestern Nebraska features fossils from the Miocene Epoch including rhinos, giant pigs, camels, and beardogs, as well as spiral-shaped, vertical burrows called Daemonelix (i.e., devil's corkscrew) excavated by a land-dwelling beaver, Palaeocastor. Pleistocene-age sediments contain mammals, reptiles, amphibians, and invertebrates. Petrified wood, opalized wood, and remains of cycads and ferns are reported from Nebraska, but their age is unspecified. The Queen Hill Quarry south of Omaha, Nebraska, produced many marine invertebrates, an impression of a large shark, and a fish skeleton. Although the age of these fossils is unspecified, they probably date to the Cretaceous Period when an inland seaway connecting the Gulf of Mexico to the Arctic Ocean bisected North America (Akersten et al. n.d.; Lane 1945; Ransom 1964; Gelbach 1965; Murray 1967; Lundberg 1975; Smith and Friedland 1975; Voorhies 1981; Weishampel et al. 1990; Holman 2000; Joeckel et al. 2001)

\section{Nevada}

Cambrian-, Ordovician-, Silurian-, Devonian-, Mississippian-, and Pennsylvanian-age invertebrates occur in Nevada, and Devonian-age fish have been found as well. Fish also occur in Permian-age rocks (Wheeler 1939). Triassic-age units contain invertebrates, fish, and marine reptiles. Berlin-Ichthyosaur State Park in the Shoshone Mountains of 
northern Nevada features carnivorous, marine reptiles from the Triassic Period called ichthyosaurs. Approximately 40 ichthyosaur skeletons have been found in the park thus far. Although these swimming reptiles look similar to dolphins, they are unrelated. The ichthyosaur fossil area is a National Natural Landmark and the historic town of Berlin is listed on the National Register of Historic Places.

Reptiles, fishes, and invertebrates occur in Jurassic-age units, and invertebrates in the Cretaceous-age rocks. Although dinosaur remains have been reported from Cretaceous-age rocks in Nevada, they are uncommon. Many different types of Neogene-age fossils occur including mammals, reptiles, amphibians, fish, invertebrates, and plants. Pleistocene-age sediments contain: mammal, bird, reptile, amphibian, and plant remains; tracks; and sloth dung (Akersten et al. n.d.; Furlong 1935; Laudermilk and Munz 1935; Wheeler 1939; Ransom 1964; Gelbach 1965; Murray 1967; Weishampel et al. 1990; Santucci 1993; Sander et al. 1994; Daniels 1998; Holman 2000).

\section{New Mexico}

Stromatolites that lived during the Proterozoic Eon are found in New Mexico. Cambrian-age fossils include traces and invertebrates, and Ordovician-age remains include stromatolites and invertebrates. Silurian-age invertebrates are reported as well. Fishes and invertebrates occur in Devonian-age rocks, and land plants, fishes, and invertebrates are found in Mississippian-age units. Pennsylvanian-age rocks have produced plants and invertebrates. Remains of reptiles, amphibians, fish, invertebrates, and plants occur in Permian-age units. Carlsbad Caverns National Park is composed of limestone that represents a massive fossil reef system, which formed when southeastern New Mexico was under the ocean during the Permian Period. This reef deposit extends into Texas and is contiguous with that found in Guadalupe Mountains National Park. The Triassic Period record in New Mexico contains many different fossil types including dinosaur, reptile, amphibian, fish, invertebrate, plant, and trace fossils. Ghost Ranch, a National Natural Landmark, contains numerous skeletons of the primitive, carnivorous, dinosaur named Coelophysis that is preserved in the Triassic Period Chinle Formation. Dinosaur and plant remains occur in the Jurassic Period, and dinosaurs, reptiles, fishes, invertebrates, plants, and trace fossils are found in the Cretaceous Period. Paleogene-age fossils include mammals, birds, reptiles, fish, invertebrates, and plants. Plant and mammal fossils occur in Neogene-age rocks, whereas Pleistocene-age sediments have mammals, birds, and reptiles (Williston 1911; Lane 1944; Ransom 1964; Murray 1967; Weishampel et al. 1990; Chronic 1994b; Holman 2000; Spearing 2001).

\section{North Dakota}

Ordovician- and Devonian-age rocks of North Dakota formed when the state was beneath an ocean and contain marine invertebrates. Mississippian-age units also formed in marine environments, and contain plant, invertebrate, and trace fossils. In the Mississippian Period Mission Canyon Formation, Luther (1995) discovered toothed jaw elements (called scolecodonts) from a segmented, marine worm (Class Polychaetia). Polychaete worms first appeared in the late Precambrian Era and are alive today. Jurassic-age invertebrates occur, and Cretaceous-age fossils include dinosaurs, reptiles, fishes, invertebrates, plants, and traces. North Dakota's state fossil is Cretaceous-age petrified wood, which exhibits borings created by a worm-shaped mollusk (Teredo). In addition to trace fossils, the remains of mammals, birds, reptiles, amphibians, fishes, invertebrates, and plants are found in Paleogene-age deposits. The only Neogene-age fossils reported from North Dakota are fish remains, whereas Pleistocene-age sediments include mammals, amphibians, fishes, invertebrates, and plants (Ransom 1964; Murray 1967; Lundberg 1975; North Dakota Geological Survey 1977; Bluemle et al. 1986; Luther 1995; Daniels 1998).

\section{Oklahoma}

Cambrian-age fish remains found in Oklahoma represent some of the oldest vertebrate fossils found in North America. Invertebrates are found in Cambrian-, Ordovician-, Silurian-, and Devonian-age units. Mississippian-age fishes and invertebrates occur. Amphibian and fish remains, amphibian tracks, and invertebrates are found in Pennsylvanian-age rocks. Permian-age fossils include reptiles, amphibians, and invertebrates. The oldest known cave/fissure deposits occur in the Slick Hills of Oklahoma, and contain fossilized reptiles from the early Permian Period. Amphibians and 
reptiles have been discovered in Triassic-age units. Jurassic-age dinosaur and trace fossils are known, as are Cretaceous-age dinosaur, vertebrate (unspecified), invertebrate, and trace fossils. Neogene-age fossils include fish, amphibian, reptile, and mammal remains. Pleistocene-age units contain mammals, birds, reptiles, amphibians, fish, and invertebrates. Petrified wood reportedly occurs in stream gravels, and although the stream deposits are probably Quaternary Period in age, it is likely that the petrified wood was reworked from an older rock unit (Shimer and Shrock 1944; Lane 1945; Ransom 1964; Gelbach 1965; Murray 1967; Lundberg 1975; Smith and Friedland 1975; Repetske 1978; Weishampel et al.1990; Holman 2000; Sullivan and Reisz 2002)

\section{Oregon}

The oldest fossils reported from Oregon are Triassic-age invertebrates. Jurassic fossils include fish and invertebrates. Rare dinosaur remains occur in Cretaceous-age rocks, along with mammal, reptile, and invertebrate fossils. Oregon has exceptional Tertiary-age fossil assemblages. John Day Fossil Beds National Monument features these Paleogene- and Neogene-age fossils, which include mammals, birds, reptiles, amphibians, fishes, invertebrates, and plants. The rocks at the Monument span approximately 48 million years and record biotic relationships, evolutionary changes, and climatic changes. Pleistocene-age animals found in Oregon include remains of mammals, birds, fishes, and invertebrates (Akersten et al. N.d.; Scharf 1935; Wilson 1935c; Lane 1947a; Ransom 1964; Gelbach 1965; Murray 1967; Lundberg 1975; Weishampel et al. 1990; Fremd 1992; Santucci 1993; Alt and Hyndman 1998a; Daniels 1998; Holman 2000).

\section{South Dakota}

Cambrian-age trace fossils are the oldest remnants of prehistoric life in South Dakota. Invertebrates and primitive, jawless, armored fish are found in Ordovician-age rocks. Devonian-, Mississippian-, Pennsylvanian-, and Permian-age invertebrates occur, and Permian-age fish have been found as well. Dinosaur, invertebrate, and trace fossils are reported from Jurassic-age units. Cretaceous deposits contain traces, plants, invertebrates, fishes, reptiles, dinosaurs, birds, and mammals. Paleogene-age fossils include mammals, birds, reptiles, fishes, invertebrates, and plants. Badlands National Park in southwestern South Dakota has Oligocene-age fossil beds that are 35-23 million years old and contain horse, sheep, rhinoceros and pig fossils. Neogene-age fossils include traces, plants, fishes, amphibians, reptiles, birds, and mammals. Remains of mammals, reptiles, and fishes are found in Pleistocene-age deposits. The Mammoth Site of Hot Springs, South Dakota (a National Natural Landmark), showcases 26,000-year-old Pleistocene-age mammoths preserved in an ancient sinkhole deposit. (Akersten et al. n.d.; Gregory 1942; Shimer and Shrock 1944; Ransom 1964; Murray 1967; Lundberg 1975; Smith and Friedland 1975; Rich 1985; Weishampel et al. 1990; Holman 2000)

\section{Texas}

In Texas, invertebrates occur in Cambrian-, Ordovician-, Silurian-, Devonian-, and Mississippian-age units, and fish are found in Ordovician-, Devonian-, and Mississippian-age formations. Pennsylvanian-age rocks contain reptiles, amphibians, fishes, invertebrates, and plants. Permian-age fossils include reptiles, amphibians, fishes, invertebrates, plants, and coprolites. Guadalupe Mountains National Park in southwestern Texas features a fossil reef system that formed when the area was a marine environment during the Permian Period. Triassic-age fossils include: dinosaur, reptile, amphibian, and fish remains; invertebrates; plants; and trace fossils. Dinosaur remains and invertebrates have been found in Jurassic-age rocks. Cretaceous-age units contain a wide variety of fossil types including dinosaur, bird, reptile, fish, invertebrate, plant, and trace. Dinosaur Valley State Park, a National Natural Landmark near Glen Rose, Texas, features Cretaceous-age dinosaur footprints that have been exposed by the Paluxy River. Paleogene-age fossils include mammals, reptiles, invertebrates, and plants. Bird remains, and mammals, reptiles, and fishes occur in Neogene-age units. Pleistocene-age sediments contain mammals, birds, reptiles, amphibians, fishes, and invertebrates (Akersten et al. n.d; Williston 1911; Shimer and Shrock 1944; Lane 1947a; Ransom 1964; Gelbach 1965; Murray 1967; Lundberg 1975; Smith and Friedland 1975; Repetski 1978; Weishampel et al. 1990; Santucci 1993; Daniels 1998; Holman 2000; Spearing 2001). 
TABLE 1

Chart Showing Subdivisions of Geologic Time and Their Age Ranges after Palmer and Geissman (1999)

\begin{tabular}{|c|c|c|c|c|}
\hline EON & ERA & PERIOD & EPOCH & AGE \\
\hline \multirow{17}{*}{ Phanerozoic } & \multirow{7}{*}{ Cenozoic } & \multirow{2}{*}{ Quaternary } & Holocene & $0.01-0 \mathrm{Ma}$ \\
\hline & & & Pleistocene & $1.8-0.01 \mathrm{Ma}$ \\
\hline & & \multirow{2}{*}{ Neogene } & Pliocene & $5.3-1.8 \mathrm{Ma}$ \\
\hline & & & Miocene & $23.8-5.3 \mathrm{Ma}$ \\
\hline & & \multirow{3}{*}{ Paleogene } & Oligocene & $33.7-23.8 \mathrm{Ma}$ \\
\hline & & & Eocene & $54.8-33.7 \mathrm{Ma}$ \\
\hline & & & Paleocene & $65-54.8 \mathrm{Ma}$ \\
\hline & \multirow{3}{*}{ Mesozoic } & Cretaceous & & $144-65 \mathrm{Ma}$ \\
\hline & & Jurassic & & $206-144 \mathrm{Ma}$ \\
\hline & & Triassic & & $248-206 \mathrm{Ma}$ \\
\hline & \multirow{7}{*}{ Paleozoic } & Permian & & $290-248 \mathrm{Ma}$ \\
\hline & & Pennsylvanian & & $323-290 \mathrm{Ma}$ \\
\hline & & Mississippian & & $354-323 \mathrm{Ma}$ \\
\hline & & Devonian & & $417-354 \mathrm{Ma}$ \\
\hline & & Silurian & & $443-417 \mathrm{Ma}$ \\
\hline & & Ordovician & & $490-443 \mathrm{Ma}$ \\
\hline & & Cambrian & & $543-490 \mathrm{Ma}$ \\
\hline Proterozoic & \multirow{2}{*}{ Precambrian } & & & $2,500-543 \mathrm{Ma}$ \\
\hline Archean & & & & $? 3,800-2,500 \mathrm{Ma}$ \\
\hline
\end{tabular}

\section{Utah}

Proterozoic-age trace fossils and stromatolites are the oldest fossils in Utah. Cambrian-age invertebrates and vertebrates (unspecified) occur, and Ordovician-age traces, invertebrates, and fishes are found as well. Fishes and invertebrates are present in Devonian-age rocks. Mississippian-age invertebrates are reported, as are Pennsylvanian-age invertebrates and plants. Invertebrate, plant, and trace fossils occur in Permian units. Triassic-age fossils include reptiles, amphibians, fishes, invertebrates, plants, and traces. Trace fossils found in Triassic-age units include vertebrate tracks, lungfish burrows, and a coprolite. Dinosaurs, mammals, reptiles, amphibians, fishes, invertebrates, plants, and traces occur in Jurassic-age rocks. Dinosaur National Monument (spanning northeastern Utah and northwestern Colorado) and Cleveland-Lloyd Dinosaur Quarry National Natural Landmark (in eastern Utah) feature Jurassic-age fauna and flora. All fossil types are present in Cretaceous-age rocks trace fossils, plants, invertebrates, fishes, amphibians, reptiles, dinosaurs, birds, and mammals. Paleogene-age fossils include mammals, reptiles, fishes, bird tracks, invertebrates, and plants. Mammal and fish remains have been found in Neogene-age rocks. Pleistocene-age deposits contain mammals, birds, reptiles, plants, and trace fossils (Akersten et al. n.d.; Dension 1951; Ransom 1964; Murray 1967; Repetski 1978; Weishampel et al. 1990; Santucci 1993; Chronic 1994c; Gillette and Hayden 1997; Holman 2000). 


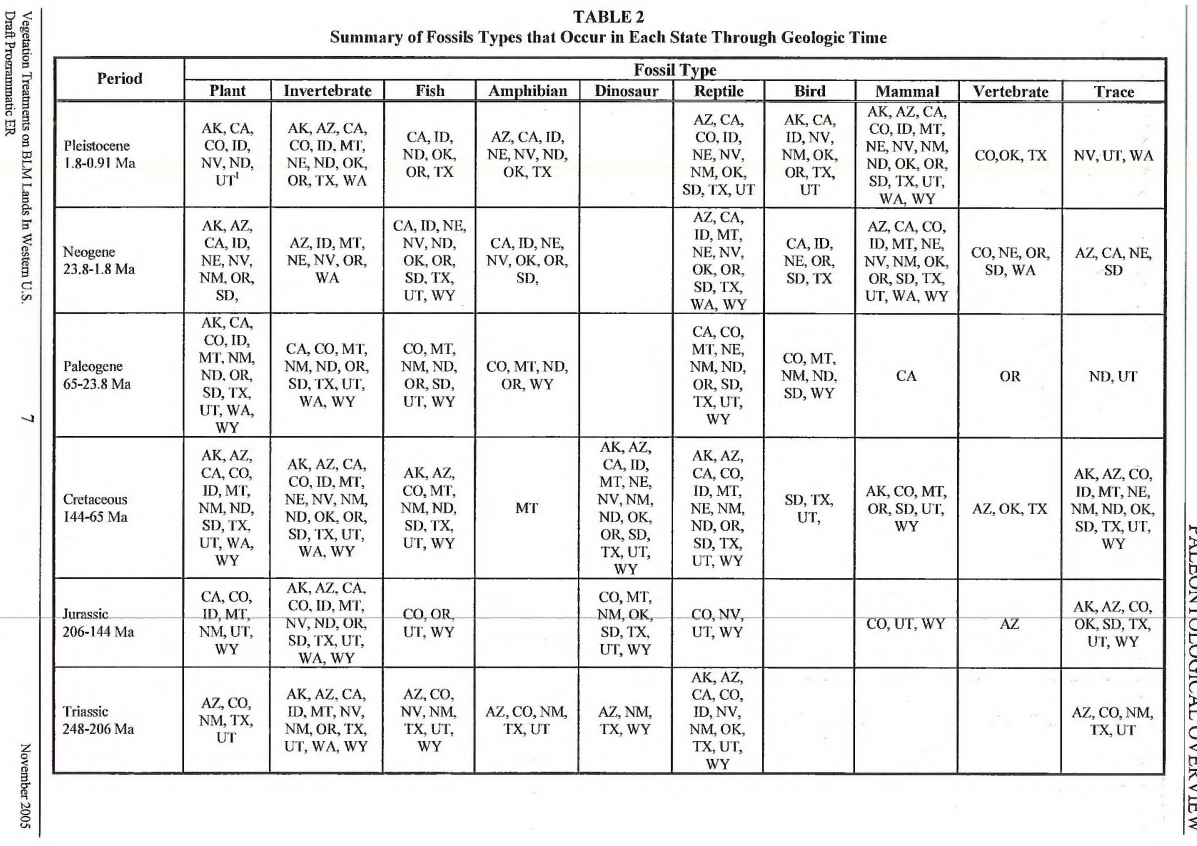


TABLE 2 (Cont.)

Summary of Fossils Types that Occur in Each State Through Geologic Time

\begin{tabular}{|c|c|c|c|c|c|c|c|c|c|c|}
\hline \multirow{2}{*}{ Period } & \multirow[b]{2}{*}{ Plant } & \multicolumn{8}{|c|}{ Fossil Type } & \multirow{2}{*}{ Trace } \\
\hline & & Invertebrate & Fish & Amphibian & Dinosaur & Reptile & Bird & Mammal & Vertebrate & \\
\hline $\begin{array}{l}\text { Permian } \\
290-248 \mathrm{Ma}\end{array}$ & $\begin{array}{c}\text { AZ, MT, } \\
\text { NM, TX, } \\
\text { UT }\end{array}$ & $\begin{array}{c}\mathrm{AK}, \mathrm{AZ}, \mathrm{CA}, \\
\mathrm{CO}, \mathrm{ID}, \mathrm{MT}, \\
\mathrm{NE}, \mathrm{NM}, \mathrm{OK}, \\
\text { SD, TX, UT, } \\
\text { WA, WY }\end{array}$ & $\begin{array}{c}\text { AZ, CA, } \\
\text { MT, NV, } \\
\text { NM, SD, } \\
\text { TX }\end{array}$ & NM, OK, TX & & $\begin{array}{l}\mathrm{CO}, \mathrm{NM} \\
\mathrm{OK}, \mathrm{TX}\end{array}$ & & & & AZ, TX, UT \\
\hline $\begin{array}{l}\text { Pennsylvanian } \\
323-290 \mathrm{Ma}\end{array}$ & $\begin{array}{c}\mathrm{AZ}, \mathrm{CO}, \\
\mathrm{NM}, \mathrm{TX} \\
\mathrm{UT}\end{array}$ & $\begin{array}{c}\mathrm{AK}, \mathrm{AZ}, \mathrm{CA}, \\
\mathrm{CO}, \mathrm{ID}, \mathrm{MT} \\
\mathrm{NE}, \mathrm{NV}, \mathrm{NM} \text {, } \\
\mathrm{OK}, \mathrm{SD}, \mathrm{TX} \\
\mathrm{UT}, \mathrm{WA}, \mathrm{WY}\end{array}$ & $\begin{array}{l}\text { MT, OK, } \\
\text { TX }\end{array}$ & OK, TX & & $\mathrm{TX}$ & & & & OK \\
\hline $\begin{array}{l}\text { Mississippian } \\
\text { 354-323 Ma }\end{array}$ & $\begin{array}{c}\text { AZ, NM, } \\
\text { ND }\end{array}$ & $\begin{array}{l}\text { AK, AZ, CA, } \\
\text { CO, ID, MT, } \\
\text { NV, NM, ND, } \\
\text { OK, SD, TX, } \\
\text { UT, WA, WY }\end{array}$ & $\begin{array}{c}\text { NM, OK, } \\
\text { TX }\end{array}$ & & & & & & & MT, ND \\
\hline $\begin{array}{l}\text { Devonian } \\
417-354 \mathrm{Ma}\end{array}$ & & $\begin{array}{c}\mathrm{AK}, \mathrm{AZ}, \mathrm{CA}, \\
\mathrm{CO}, \mathrm{MT}, \mathrm{NV}, \\
\mathrm{NM}, \mathrm{ND}, \mathrm{OK}, \\
\mathrm{SD}, \mathrm{TX}, \mathrm{UT}, \\
\text { WA, WY }\end{array}$ & $\begin{array}{l}\text { AZ, CA, } \\
\text { CO, ID, } \\
\text { MT, NV, } \\
\text { NM, TX, } \\
\text { UT, WY }\end{array}$ & & & & & & & MT \\
\hline $\begin{array}{l}\text { Silurian } \\
443-417 \mathrm{Ma}\end{array}$ & MT & $\begin{array}{c}\text { AK, CA, MT, } \\
\text { NV, NM, OK, } \\
\text { TX }\end{array}$ & & & & & & & & \\
\hline $\begin{array}{l}\text { Ordovician } \\
490-443 \mathrm{Ma}\end{array}$ & NM & $\begin{array}{c}\text { AK, CA, CO, } \\
\text { ID, MT, NV, } \\
\text { NM, ND, OK, } \\
\text { SD, TX, UT, } \\
\text { WA, WY }\end{array}$ & $\begin{array}{l}\mathrm{CO}, \mathrm{MT}, \\
\mathrm{SD}, \mathrm{TX} \\
\mathrm{UT}, \mathrm{WY}\end{array}$ & & & & & & & $\mathrm{CO}, \mathrm{MT}, \mathrm{UT}$ \\
\hline $\begin{array}{l}\text { Cambrian } \\
543-490 \mathrm{Ma}\end{array}$ & & $\begin{array}{c}\text { AK, AZ, CA, } \\
\text { CO, ID, MT, } \\
\text { NV, NM, OK, } \\
\text { SD, TX, UT, } \\
\text { WA, WY }\end{array}$ & $\begin{array}{c}\text { OK, WA, } \\
\text { WY }\end{array}$ & & & & & & UT & $\mathrm{NM}, \mathrm{SD}$ \\
\hline $\begin{array}{l}\text { Proterozoic } \\
2,500-543 \mathrm{Ma}\end{array}$ & $\begin{array}{l}\text { AZ, ID, } \\
\text { MT, NM, } \\
\text { UT, WY }\end{array}$ & $\mathrm{AZ}, \mathrm{MT}$ & & & & & & & & ID, MT, UT \\
\hline Age unspecified & $\begin{array}{l}\mathrm{AK}, \mathrm{NE} \\
\mathrm{NV}, \mathrm{OK}\end{array}$ & $\mathrm{AK}, \mathrm{NE}$ & $\mathrm{NE}$ & & & & & & & $\therefore$ \\
\hline
\end{tabular}




\section{Washington}

Cambrian-age fish remains from Washington are some of the oldest vertebrate remains found in North America. Invertebrates occur in Cambrian-, Ordovician-, Devonian-, Mississippian-, Pennsylvanian-, Permian-, Triassic-, and Jurassic-age rocks. Cretaceous- and Paleogene-age fossils include invertebrates and plants. Neogene-age deposits contain mammal, reptile, and unspecified vertebrate remains; invertebrates; petrified wood; and leaf impressions. Gingko Petrified Forest, a state park near Ellensburg, Washington, is a National Natural Landmark featuring Mioceneage petrified wood that was preserved when "...lava covered waterlogged wood buried in the mud in the bottom of a shallow lake." Mammals, invertebrates, and trace fossils are found in Pleistocene-age sediments (Akerstein et al. n.d.; Ransom 1964; Murray 1967; Repetski 1978; Alt and Hyndman 1998b; Daniels 1998; Holman 2000).

\section{Wyoming}

Proterozoic-age stromatolites occur in Wyoming. Some of the oldest fish remains discovered in North America come from this state, and are found along with invertebrates and calcareous algae in Cambrian-age rocks. Ostracoderms (fish) and invertebrates are found in Ordovician-age units. Devonian-age rocks contain fish, whereas invertebrates occur in Mississippian-, Pennsylvanian-, and Permian-age units. Triassic-age dinosaurs, reptiles, fishes, and invertebrates are present. Jurassic fossils are diverse and include mammals, dinosaurs, reptiles, amphibians, fishes, invertebrates, plants, and traces. Red Gulch Dinosaur Track Site on public land near Shell, Wyoming, showcases 167 million-year-old dinosaur tracks from the Jurassic Period and is the largest track site in the state. Cretaceous-age units contain trace fossils, plant remains, invertebrates, fish, reptiles, dinosaurs, and mammals. Paleogene-age formations have produced mammals, birds, reptiles, amphibians, fishes, invertebrates, and plants. Fossil Butte National Monument is well known for its fossil fish, but it also protects plant, insect, reptile, and mammal fossils preserved in 50 million-year-old Eoceneage lake deposits. Neogene-age deposits contain mammal, reptile, and fish remains. Ice Age mammals have been found in Pleistocene-age sediments (Akersten et al. n.d.; Shimer and Shrock 1944; Lane 1945; Ransom 1964; Murray 1967; Lundberg 1975; Repetski 1978; Dorr 1985; Lageson and Spearing 1988; Weishampel et al. 1990; Chronic 1994a; Holman 2000). 


\section{REFERENCES}

Akersten, W.A., H.G. McDonald, D.J. Meldrum, and M.E.T. Flint (eds.). n.d. And Whereas...Papers on the Vertebrate Paleontology of Idaho Honoring John A. White. Volume 1. Occasional Paper 36. Idaho Museum of Natural History. Pocatello, Idaho.

Alt, D.D., and D.W. Hyndman. 1986. Roadside Geology of Montana. Mountain Press. Missoula, Montana. . 1995. Roadside Geology of Idaho. Mountain Press. Missoula, Montana. . 1998a. Roadside Geology of Oregon. Mountain Press. Missoula, Montana. . 1998b. Roadside Geology of Washington. Mountain Press. Missoula, Montana.

Montana. 2000. Roadside Geology of Northern and Central California. Mountain Press. Missoula,

Balster, C.A. 1971. Catalog of Stratigraphic Names for Montana. Special Publication 54. Bureau of Mines and Geology. Butte, Montana.

Bluemle, J.P., S.B. Anderson, J.A. Andrew, D.W. Fischer, and J.A. LeFever. 1986. North Dakota Stratigraphic Column. Miscellaneous Series 66. North Dakota Geological Survey. Bismark, North Dakota.

Bode, F.D. 1935. Tooth Characters of Protohippine Horses with Special Reference to Species from the Merychippus Zone, California. Publication No. 453. Pages 39-63 in Contributions to Palaeontology. Carnegie Institution of Washington, D.C.

Carroll, R.L. 1988. Vertebrate Paleontology and Evolution. W.H. Freeman. New York, New York.

Chronic, H. 1989. Roadside Geology of Arizona. Mountain Press. Missoula, Montana.

. 1994a. Roadside Geology of Colorado. Mountain Press. Missoula, Montana.

1994b. Roadside Geology of New Mexico. Mountain Press. Missoula, Montana.

1994c. Roadside Geology of Utah. Mountain Press. Missoula, Montana.

Connor, C., and D. O'Haire. 2001. Roadside Geology of Alaska. Mountain Press. Missoula, Montana.

Daniels, F.J. 1998. Petrified Wood: The World of Fossilized Wood, Cones, Ferns, and Cycads. Western Colorado. Grand Junction, Colorado.

Deiss, C. 1939. Cambrian Stratigraphy and Trilobites of Northwestern Montana. Special Papers Number 18. Geological Society of America. Boulder, Colorado.

Denison, R.H.1951. Late Devonian Fresh-water Fishes from the Western United States. Fieldiana: Geology 11(5):221-261.

Dorr, Jr., J.A. 1985. Newfound Early Cretaceous Dinosaurs and Other Fossils in Southeastern Idaho and Westernmost Wyoming. Contributions from the Museum of Paleontology, University of Michigan 27(3):7385. 
Fremd, T. 1992. "I've Seen the Miocene" in Central Oregon. Park Science 12(3):12-13.

Furlong, E.L. 1935. New Merycodonts from the Upper Miocene of Nevada. Publication No. 453. Pages 1-10 in Contributions to Palaeontology, Carnegie Institution of Washington. Washington, D.C.

Gelbach, F.R. 1965. Amphibians and Reptiles from the Pliocene and Pleistocene of North America: A Chronological Summary and Selected Bibliography. Texas Journal of Science 17(1):56-70.

Gillette, D.D., and M.C. Hayden. 1997. A Preliminary Inventory of Paleontological Resources Within the Grand Staircase-Escalante National Monument, Utah. Circular 96. Utah Geological Survey. Salt Lake City, Utah.

Gregory, J.T. 1942. Pliocene Vertebrates from Big Spring Canyon South Dakota. University of California Publications, Bulletin of the Department of Geological Sciences 26(4):307-446.

Hill, C.L. (ed.). 2001. Guidebook for the Field Trips of the SVP $61^{\text {st }}$ Annual Meeting; Mesozoic and Cenozoic Paleontology in the Western Plains and Rocky Mountains. Occasional Paper No. 3. Museum of the Rockies. Bozeman, Montana.

Holman, J.A. 2000. Fossil Snakes of North America: Origin, Evolution, Distribution, Paleoecology. Indiana University Press. Bloomington, Indiana.

Horner, J.R. 1989. The Mesozoic Terrestrial Ecosystems of Montana. Pages 153-162 in Northwest Montana and Adjacent Canada: Montana Geological Society 1984 Field Conference and Symposium (J. D. McBane and P. B. Garrison, eds.). Montana Geological Society. Billings, Montana.

Joeckel, R.M.J., Cunningham, P. L. Phillips, G.A. Ludvigson, B.J. Witzke, R.G. Corner, and G.W. Brown. 2001. The First Report of Dinosaur Tracks from Nebraska. Journal of Vertebrate Paleontology 21:66A.

Kuntz, D.W., H.J. Armstrong, and F.J. Athearn (eds.). 1989. Faults, Fossils, and Canyons; Significant Geologic Features on Public Lands in Colorado. Cultural Resource Series, Number 25. Bureau of Land Management, Colorado State Office. Lakewood, Colorado.

Lageson, D.R., and D.R. Spearing. 1988. Roadside Geology of Wyoming. Mountain Press. Missoula, Montana.

Lane, H.H. 1944. A Survey of the Fossil Vertebrates of Kansas; Part I: The Fishes. Transactions of the Kansas Academy of Science 47(2):129-176.

1945. A Survey of the Fossil Vertebrates of Kansas; Part II: Amphibia. Transactions of the Kansas Academy of Science 48(3):286-316.

1946. A Survey of the Fossil Vertebrates of Kansas; Part III: The Reptiles. Transactions of the Kansas Academy of Science 49(3):289-332.

. 1947a. A Survey of the Fossil Vertebrates of Kansas; Part IV: Birds. Transactions of the Kansas Academy of Science 49(4):390-400.

Laudermilk, J.D., and P.A. Munz. 1935. Plants in the Dung of Nothrotherium from Gypsum Cave, Nevada. Publication No. 453. Pages 29-37 in Contributions to Palaeontology, Camegie Institution of Washington. Washington, D.C.

Lundberg, J.G. 1975. The Fossil Catfishes of North America. University of Michigan Museum of Paleontology, Papers on Paleontology 11:1-51. 
Luther, M. 1995. "Micro-Jaws I! (aka, Scolecodonts)." North Dakota Geological Survey Newsletter 22(4):21-25.

Murray, M. 1967. Hunting Fossils: A Guide to Finding and Collecting Fossils in All Fifty States. Macmillan. New York, New York.

North Dakota Geological Survey. 1977. "Fossils in North Dakota." North Dakota Geological Survey Newsletter (June Issue).

Ransom, J.E. 1964. Fossils in America. Harper and Row. New York, New York.

Rasmussen, D.L. 1974. New Quaternary Mammal Localities in the Upper Clark Fork River Valley, Western Montana. Northwest Geology 3:62-69.

Repetski, J.E. 1978. A Fish from the Upper Cambrian of North America. Science 200:529-531.

Rich, F.J. (ed.). 1985. Geology of the Black Hills, South Dakota and Wyoming. American Geological Institute. Alexandria, Virginia.

Sander, P.M., O.C. Rieppel, and H. Bucher. 1994. New Marine Vertebrate Fauna from the Middle Triassic of Nevada. Journal of Paleontology 68(3):676-680.

Santucci, V.L. 1993. National Park Service Paleontological Research Abstract Volume. NPS D-815 June 1993. U.S. Department of the Interior, National Park Service Western Region, Petrified Forest National Park, Arizona.

Scharf, D.W. 1935. A Miocene Mammalian Fauna from Sucker Creek, Southeastern Oregon. Publication No. 453, Pages 97-118 in Contributions to Palaeontology, Carnegie Institution of Washington. Washington, D.C.

Sharp, R.P., and A.F. Glazner. 1993. Geology Underfoot in Southern California. Mountain Press. Missoula, Montana.

Shimer, H.W., and R.R. Shrock. 1944. Index Fossils of North America. John Wiley and Sons. New York, New York.

Smith, G.R., and N.E. Friedland. 1975. Studies on Cenozoic Paleontology and Stratigraphy. University of Michigan Museum of Paleontology, Papers on Paleontology 12:1-143.

Spearing, D. 2001. Roadside Geology of Texas. Mountain Press. Missoula, Montana.

Sullivan, C.S., and R. Reisz. 2002. Lower Permian Fissure Deposits in the Slick Hills, Oklahoma, the Oldest Known Fossiliferous Paleokarst. Journal of Vertebrate Paleontology 22:112A.

Thurston, D.K., and K. Fujita (eds.). 1994. 1992 Proceedings International Conference on Arctic Margins. U.S. Department of the Interior, Minerals Management Service. Washington, D.C.

Voorhies, M.R. 1981. Dwarfing the St. Helens Eruption; Ancient Ashfall Creates a Pompeii of Prehistoric Animals. National Geographic 159(1):66-75.

Weishampel, D.B., P. Dodson, and H. Osmólska (eds.). 1990. The Dinosauria. University of California Press. Berkeley, California.

Wheeler, H.E. 1939. Helicoprion in the Anthracolithic (late Paleozoic) of Nevada and California, and Its Stratigraphic Significance. Journal of Paleontology 13(1):103-114. 
Willis, B. 1902. Stratigraphy and Structure, Lewis and Livingston ranges, Montana. Geological Society of America Bulletin 13:305-352.

Williston, S.W. 1911. American Permian Vertebrates. University of Chicago Press. Chicago, Illinois.

Wilson, R.W. 1935a. Two Rodents and a Lagomorph from the Sespe of the Las Posas Hills, California. Publication No. 453. Pages 11-17 in Contributions to Palaeontology, Carnegie Institution of Washington. Washington, D.C.

.1935b. Artiodactyla From the Sespe of the Las Posas Hills, California. Publication No. 453. Pages 119125 in Contributions to Palaeontology, Carnegie Institution of Washington. Washington, D.C.

1935c. A New Species of Dipoides from the Pliocene of Eastern Oregon. Publication No. 453. Pages 19-28 in Contributions to Palaeontology, Carnegie Institution of Washington. Washington, D.C. 


$$
\begin{aligned}
& \text { W WA MANGEMENT LIBRARN } \\
& \text { QTG. 50, STA A } 36 \text { ALENTER } \\
& \text { P. BOX } 25047 \text { COLADO } 80225 \\
& \text { ENVE }
\end{aligned}
$$
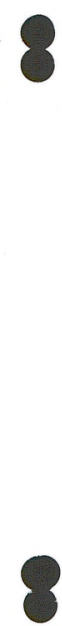

• 